Forthcoming in the 2015 Proceedings of the American Catholic Philosophical Association

\title{
How Must We Be for the Resurrection to Be Good News?
}

\author{
Chad Engelland \\ [cengelland@udallas.edu] \\ University of Dallas
}

\begin{abstract}
While the promise of the resurrection appears wonderful, it is also perplexing: How can the person raised be one and the same person as the one that dies? And if the raised person is not the same, why should any of us mortals regard the promise of the resurrection as good news? In this paper, I articulate the part-whole structure of human nature that supports belief in the sameness of the resurrected person's identity and the desirability of the resurrection: (1) the immaterial core of the person must survive the destruction of the body; (2) the person must nonetheless be incomplete apart from the body; and (3) the personal core must be the source for the personal identity of the resurrected body. In light of these criteria, I conclude by arguing that survivalism rather than corruptionism is the more compelling account of death and resurrection present in the thought of St. Thomas Aquinas.

Key words: Death, Resurrection, Personal Identity, Human Nature, Peter Geach, Thomas Aquinas
\end{abstract}

Blaise Pascal memorably maintained that the fear of death motivates the diversions of mankind: "Being unable to cure death, wretchedness and ignorance, men have decided, in order to be happy, not to think about such things."1 The possibility that we should cease to exist or, continuing to exist, should cease to have our bodily way of being, is naturally a terrifying possibility. St. Augustine thinks we have an "obvious natural revulsion to annihilation,", St. Thomas Aquinas thinks that "everything that has an intellect naturally desires always to exist,"3 St. John Paul II thinks that in us "there is an irrepressible longing to live forever," and Socrates

1. Pensées, trans. A. J. Krailsheimer (New York: Penguin Books, 1995), p. 37.

2. City of God, trans. Henry Bettenson (New York: Penguin Books, 1972), 11.27. To support this claim, he says that if people were given the choice of immediately ceasing to be or living a longer life of misery, they would choose the latter.

3. Summa Theologiae, trans. Fathers of the English Dominican Province (New York: Benzinger Brothers, 1948), I, q. 75, a. 6. The senses are rooted in the here and now but the intellect apprehends things without temporal limitation.

4. Pope St. John Paul II, Apostolic Letter Tertio Millennio Adveniente, November 10, 1994, no. 9. 
says "I have good hope that some future awaits men after death." Now, Christianity claims to have some good news on this score. We are not only promised immortality as hoped for by a philosopher such as Socrates; we are promised the resurrection of our flesh, a possibility unanticipated by any philosopher-not even by Heraclitus, who counsels us to expect "the unexpected." ${ }^{\prime 6}$ Surely, if this is a credible promise, it is good news. We need only recall its original proclamation to philosophers. St. Paul came to Athens and engaged with Epicurean and Stoic philosophers, who, like all Athenians, always wanted to hear something new. St. Luke records their reaction to the resurrection as follows: "Now when they heard of the resurrection of the dead, some mocked; but others said, "We will hear you again about this.",7 The promise that Jesus will make all things new is so unexpected that even those who only want to hear novelties wanted to hear of it again.

Beyond the question of credibility, which is an issue for faith and theology, I want to isolate a specifically philosophical concern. While the resurrected person may appear to others and to himself to be the same person as I am now, it is not immediately clear that it really could be me. Why wouldn't the resurrected person be merely a clone that thinks he is the same as me? I want to ask philosophically, to the extent that it is a philosophical question, whether hope in my resurrection makes sense. Is the prospect of the dead's resurrection good news or only apparently good news? I think it is good news provided we understand the human person in a very particular kind of way, and I want to spell out the basic features of that way here.

I offer the following as conditional: what part-whole structure of human nature is necessary if the resurrection of the dead is to be meaningful to each of us? My thesis is that the

5. Plato, Phaedo, in Plato: Complete Works, ed. John Cooper (Indianapolis, IN: Hackett, 1997), 63c.

6. The Art and Thought of Heraclitus, trans. Charles Kahn (Cambridge: Cambridge University Press, 1979), p. 31. For Heraclitus's provocative musings on the reversibility of death, akin to the alterations of the seasons or the interplay of waking and sleeping, see Kahn, pp. 210-227.

7. Acts 17:32 (RSV). 
resurrection requires an intellective hylomorphism: a dependent part (the body) that ceases to be at death and is restored later, and an independent part (the soul) that persists through death, establishes my selfhood, and causes the body to be, thereby making the restored body one and the same body. According to hylomorphism, soul and body constitute a single substance; according to intellective hylomorphism, the human soul not only animates the body, it can also exist in an incomplete fashion apart from the body. Death does not corrupt the soul, which is the personal core. This paper weighs in on the contemporary debate between corruptionists and survivalists among Thomistically inspired hylomorphic accounts of mind. The corruptionists think that the dead person is no longer a person; the survivalists think that the dead person remains the same person. In this paper, I side with survivalism against corruptionism; on my view, for the resurrection to be good news for each of us now living, survivalism must obtain.

\section{I.}

Why No Proxy Will Do. The resurrection of the dead appears as good news contrasted with the two apparent alternatives: existing in a disembodied manner in some mythical land of the dead or the immediate annihilation of self with the possibility of existing through some kind of proxy. The possibility of disembodied personal existence is manifestly dissatisfying, especially when we consider our loved ones, whom we love as embodied; that they will rise again, body and all, is very good news indeed. Compared to the possibility of existing through some kind of proxy, the resurrection is extremely good news, for, in the last analysis, existence through proxy is not personally satisfying. I cannot say of the proxy, "I, Chad Engelland, will still be Chad Engelland in virtue of that item." Consider the various candidates for proxy: 
reincarnation, progeny, fame, works, or in the latest hope, a computer program. ${ }^{8}$ For reincarnation, how am I the same as the person from a former or future life? Not in terms of the body, not in terms of memories and experience, but just in terms of the bare soul-substance; yet this continuity is akin to the anonymous self-identity of a rock; it is not a living or personal identity; I now cannot say, I, Chad Engelland, will be the same person then as now. Saul Kripke seems right to say that the identity of one's parents is essential for personal identity: "How could a person originating from different parents, from a totally different sperm and egg, be this very woman? ... It seems to me that anything coming from a different origin would not be this object." ${ }^{, 9}$ Reincarnation maintains that the parents are incidental; this means that reincarnation does not grant the sort of personal immortality that we naturally long for. For living through descendants, I continue only as a fainter and fainter echo: a biological inheritance that didn't entirely belong to me, a generous link in a chain of generations, and a living memory forgotten after several generations; as for living through one's works, deeds, or a computer simulation, I do not live, but a limited appearance of me might; still this is not the same as me. I am no longer there to experience and be experienced "in person." Having a photograph of a loved one is no real substitute for having that loved one himself or herself. If what we really want is to continue to be as the person each of us is now and for loved ones to exist as they are now, the proxy provides little consolation. Consider the desire that motivated the Ted Williams family to resort to cryogenics: "This is what we want, to be able to be together in the future, even if it is only a chance." ${ }^{10}$ We want to be together in the future and that means that each of us must really be.

\footnotetext{
8. Stephen Hawking, for example, said, "I think the brain is like a programme in the mind, which is like a computer, so it's theoretically possible to copy the brain on to a computer and so provide a form of life after death." Dailymail.com, 21 September 2013, accessed February 27, 2015.

9. Naming and Necessity (Malden, MA: Blackwell Publishing, 1981), p. 113.

10. Richard Sandomir, "Note Dated 2000 Says Williams Wanted His Remains Frozen," New York Times,
} July 16, 2002. 
The proxy falls prey to vanity, for it is not what we really want. Rather it is a pale and ultimately unsatisfying substitute for personal immortality. As Woody Allen puts it, "I don’t want to achieve immortality through my work, I want to achieve immortality through not dying."11

Opposed to the impersonal immortality of the proxy, resurrection promises personal immortality: "I, Chad Engelland, will continue to be as Chad Engelland thanks to the resurrection of the dead." It is apparently great news. And yet the resurrection of the dead is puzzling. Can it really distinguish itself from impersonal immortality? Resurrection holds that at some unspecified future point, the dead will come back to life. How can this resurrected person be the same person as each of is now? Might it not be another person? In such a case, the resurrected person would in effect be a proxy for the person that died.

What does human personal identity require? We are not angels. The story of our genesis is essential to our identities. To be the same person, I must be the son of the same parents who came together at a particular time. ${ }^{12}$ But this is not enough for the same could be said of an identical twin. Personal identity also requires the same agency of experience. As a newborn, I looked up into my parents' eyes and smiled. They saw my affectivity, the fact that experience happens for me, and I saw in their eyes their affectivity, the fact that experience happens for each of them. ${ }^{13}$ To be the same person means that we remain the same dative and agent of experience. Metaphysically, this requires that the same subject persist, for the agency of experience is an expression of this being. Each of us takes in the world from our own vantage points thanks to the fact that each is a separate being. There are at least three interrelated factors for personal identity:

11. Quoted by Sam B. Girgus, "Afterword: The Abyss: Woody Allen on Love, Death, and God," in $A$ Companion to Woody Allen, ed. Peter J. Baily and Sam B. Girgus, 559-572 (Malden, MA: Wiley-Blackwell, 2013), p. 570. forthcoming.

12. See Chad Engelland, "On the Personal Significance of Sexual Reproduction," The Thomist,

13. See Chad Engelland, “Unmasking the Person,” International Philosophical Quarterly 50 (2010): 447460. 
the resurrected person must [a] have the same genesis, [b] have lived the same life, and [c] be the same subject as the person before he or she died.

Why think that sameness requires continuity of existence? Why cannot the sameness be realized on the side of the creator? Surely if God can create a being at one time he can recreate the same one being at another time, outfitted with the same genealogy, the same experiences, and the same subject. Let me spell out why I do not think this is the case. First, the recreated person would have a different story of its origins; rather than coming to be through the secondary causality of particular parents at a particular time, the recreated person would come to be independent of secondary causes at another time. Second, while the recreated person would likely be outfitted with the same memories as the original person, those memories would not be the fruit of experience; they would be memories of a life lived by another being. Third, the recreated person would not be the same subject, for a subject is not just something with a certain intelligibility; it is something with a particular act of being. The particular act of being does not merely actualize a certain divine idea; the particular act of being constitutes the root and ground of personal identity, which makes real my particular essence and activities. I am my act of being. While the "idea" may be the same in the recreated being, the act of being could not be; therefore the being would not in fact be the same.

In view of the above, we can say that the sameness of the resurrected must be realized in the creature; it cannot be realized simply on the side of the creator. W. Norris Clarke, SJ, puts it this way:

The recreated entity might be a clone, like me in many ways, but not the same unique personal $m e$, because the new unity, the self — the "I"—organizing the similar body is not the same as me, for the simple reason that it never experienced the same personal life, the same story with all its challenges, successes and failures, that became an inseparable part of my identity before my death. That self is simply gone, and not even the omnipotence of God can do what is a metaphysical impossibility: recreate the identical being that 
existed before, with no bond of continuity on the personal level between the before and the after. ${ }^{14}$

I want to think how we must be in order for the resurrection to be in fact good news, not just apparently good news. What are the necessary principles of human nature?

II.

The Criteria for Resurrected Identity. Let us take death to be the end of bodily being and resurrection to be the beginning again of bodily being. I regard this understanding of death to be a basic fact, confirmed both by ordinary experience and by philosophical and scientific investigation. The living body not only undergoes metabolic activity, it not only evidently perceives, feels, and moves, but it also serves to express the specifically human life of the mind. The corpse, by contrast, undergoes no such vital, perceptual, or personal activities. Moreover, the unity it heretofore enjoyed appears to be irremediably compromised. It is therefore not the same thing. What is it? A naturally occurring likeness of the person's body that once was. The frightful absence that marks the corpse marks a radical change of being. My sense of the resurrection comes from Christian witness: the resurrection of Christ as firstborn from the dead and the bold proclamation that the restoration of our bodily selves, spiritualized, is a possibility that will be actualized for all. ${ }^{15}$ It is a basic feature of orthodox Christian teaching.

14. The Creative Retrieval of St. Thomas Aquinas: Essays in Thomistic Philosophy, New and Old (New York: Fordham University Press, 2009), p. 188.

15. See, for example, The Catechism of the Catholic Church, no. 997: "In death, the separation of the soul from the body, the human body decays and the soul goes to meet God, while awaiting its reunion with its glorified body. God, in his almighty power, will definitively grant incorruptible life to our bodies by reuniting [coniungens] them with our souls, through the power of Jesus' Resurrection." For a theological overview of the issue, see Joseph Ratzinger, Eschatology: Death and Eternal Life, trans. Michael Waldstein and Aidan Nichols, OP (Washington, DC: The Catholic University of America Press, 1988), pp. 69-214. He writes, "How can there be an identity between the human being who existed at some point in the past and the counterpart that has to be re-created from nothing? The irritated refusal of such questions as 'philosophical' does not contribute to a more meaningful discussion" (p. 106). 
In order for the hope in the resurrection not to be empty, I think the following three criteria must hold:

[1] The Principle of Personal Persistence: When Patches the rabbit is run over by a bus, it perishes. The act of violence compromises the unity of the whole with a total loss of being; what remains, the carcass, was but no longer is a rabbit. Patches as a whole and in all its parts has ceased to be. Could God resurrect Patches? God could create a being just like Patches down to the last detail but, without some principle of continuity in being, it would not be Patches but a clone of Patches. From the point of view of the pet owner, that might not be a big deal; Patches's own point of view is not relevant, for Patches is not a person, not a spiritual being with a desire for immortality. But for humans, our own point of view is not irrelevant regarding our own death and resurrection and the death and resurrection of our loved ones. It is not enough for clones of us to be restored. It must really be us for this possibility to be personally satisfying. What enables the resurrected self to be the same self? There must be a principle safeguarding personal continuity; unlike the case of Patches the rabbit, death must not be the end of the entire substance. Of course, it is a basic fact that death, whether for Patches or for me, must involve the destruction of the body. But though I am my body I am not only my body. If I lose my leg, I am still human even though I am not a complete human being. Similarly, if I lose all my limbs I am still human even though I am not a complete human being. Finally, if I lose my whole body in death, I am still human even though I am not a complete human being. Privation can extend not just to the body part but to the whole part of us that is the body. Now, this privation of a whole metaphysical part is an extreme form of privation. My personal core must survive this extreme privation so that Chad Engelland alive and Chad Engelland resurrected would be the same person. The principle of personal persistence identifies that, as a condition for maintaining the 
identity of a person there must be something more than the bodily being that manifestly ceases to be with the event of death. And this persisting principle must be personal. For example, it would not do for just the teeth of the person to persist; it must be that which somehow instantiates the person.

Can't our bodies constitute personal identity? Can't we say, with Peter van Inwagen and other materialists, that God could, despite the appearances, somehow preserve the bodily organism, that, in effect, we will only appear to die ${ }^{16}$ Such conjuring is metaphysically possible, but it questions one of the basic facts of the case, which is that we know people die and their bodies decompose. ${ }^{17}$ It also serves to deny that there is such a thing as the resurrection. Rather, the resurrection on this view is not something that will happen in the future; it is rather a code name for something that God already always does: makes it appear like people die while carting their living bodies off to somewhere else. It's van Inwagen's materialism that leads him to question the basic fact of death and to reinterpret the resurrection. Instead, I want to think of a way to make sense of the possibility of the resurrection that preserves the reality of the appearances and leaves the resurrection as a hoped-for futural event. Like Augustine and Aquinas, I do not find materialism compelling, and I can therefore accept the fact of death as something that's not illusory. ${ }^{18}$ Van Inwagen is right to insist on a principle of continuity, but the

16. “The Possibility of Resurrection,” International Journal for Philosophy of Religion 9 (1978): 114-121.

17. Van Inwagen distinguishes between "suspension of life," in which the organism enters into a reversible metabolic rest, such as a frozen cat, which could in principle be resuscitated, and "disruption of life," in which the organism ceases to exist. At the human death, the person's life is suspended but there remains a possibility for reanimation. But to maintain that the dead has only died in the first sense and not in the second he has to resort to metaphysical conjuring, and say that what we see evidently decomposing is not really the remains of the body, for the body has been whisked away and been replaced with this imitation. See Material Beings (Ithaca, NY: Cornell University Press, 1990), p. 147, and “The Possibility of Resurrection," pp. 119-121.

18. Among the many problems with materialism is its inability to account for the fact that we can show things to each other. See Chad Engelland, Ostension: Word Learning and the Embodied Mind (Cambridge, MA: MIT Press, 2014), chapters 8-10. Another problem is its inability to account for the normativity of truth. See Chad Engelland, "Heidegger and the Human Difference," Journal of the American Philosophical Association 1 (2015): 175-193. 
body, evidently demising, is not the most promising candidate in our metaphysical makeup for this feat.

If the body does not account for personal persistence, what part can? The soul must not be bodily; it must be able to persist apart from the decomposing body, and it must constitute the root of personal identity. ${ }^{19}$ As Augustine puts it, we love the deceased Apostle, because "we believe that what we love in him lives even now, for we love his just rational soul [animus]. ${ }^{, 20}$ If the body ceases to be and yet the person continues to exist, there must be some non-bodily dimension of the person that survives. Now, we might resist the thought that the person, a bodysoul composite, could somehow be the same person even while missing an essential part, the body. But, granting that the soul can exist apart from the body, we can see that it can in fact exist as the same human person provided that it contains virtually the powers of the non-existent body. Consider some relatively uncontroversial analogues. When we are sleeping, we are generally not exercising our higher order linguistic capacities, but we retain those powers in potentiality. Even though speaking is essential to us as human beings, it does not have to be continually exercised for us to be the human beings that we are. When we were babies, we did not even have the developed capacity to speak. We could still be human, without this essential attribute's development, because our nature remained as it were primed for this development. In fact, for our natural ability to speak to develop, we had to be exposed to the speech of others; feral children, for example, develop neither semantics nor syntax; consequently, natural powers can rest on extrinsic factors for their realization. ${ }^{21}$ Infants and feral children, despite this lack, are nonetheless essentially human. Similarly, the soul of the dead person, bereft of the body, retains

19. See Clarke, Creative Retrieval, p. 189.

20. On the Trinity, trans. Stephen McKenna (Washington, DC: The Catholic University of America Press, 1963), 8.6.9. On Augustine's non-dualistic philosophical anthropology, see Chad Engelland, "Perceiving Other Animate Minds in Augustine," American Catholic Philosophical Quarterly, forthcoming.

21. Derek Bickerton, Language and Species (Chicago: University of Chicago Press, 1990), pp. 115-118. 
the human capacity to animate a body; though it lacks an essential part, it retains its essential ordering to that part. The separated soul remains primed for an actuality it cannot realize on its own.

[2] The Personal Relevance of the Absent Body: Unlike the case of Patches the rabbit, the human soul must be able to survive the event of death in order for the resurrected person to be the same as he or she is now. That means that in the case of humans, death must not be a substantial change; the body ceases to be, while the person does not. But for the resurrection to be good news, our bodies, as inessential as they are for our bare existence must nonetheless be essential for the living out of our human lives. The demise of the body must remain something other than a mere accidental change. Otherwise there would be no serious reason for each of us to hope in the resurrection. Set free from the tomb of the body we could look upon the prospect of a resurrection with disinterest. If the resurrection of the dead is good news, substance dualism, whether of the sort advocated by Plato or by Descartes, must not obtain. For the resurrection to be anticipated, the body must be part of what we are. Augustine expresses this twofold whatness with admirable precision: "Man is a rational substance consisting of soul and body." 22 While our personal core, who we are, might persist through the death of the body, we nonetheless would remain less than what we are-unless the resurrection of the dead should occur.

Our bodies are also essential to how we are. To be a human is to be a being that can experience, act, and show things to each other. ${ }^{23}$ What would life without our bodies be like? Because we lack experience of it, we cannot say with confidence what will be natural to us then, but we can be confident that for human nature as we experience it now, our bodies are essential.

22. On the Trinity, 15.7.11.

23. For a classical treatment, see Maurice Merleau-Ponty, Phenomenology of Perception, trans. Colin Smith (London: Routledge Classics, 2002); for recent restatements, see Maxine Sheets-Johnstone, “Animation: The Fundamental, Essential, and Properly Descriptive Concept," Continental Philosophy Review 42 (2009): 375-400, and Chad Engelland, Ostension: Word Learning and the Embodied Mind. 
Without our bodies as the instruments of experience we would presumably have total emptiness of experience. We could not speak or be spoken to, we could not see or be seen, and we could not give or receive. Nor, does it seem, could we relive our memories, lost as they would be with the death of the body and the loss of our brains. It seems possible that we might achieve selfawareness and other peculiarly intellective acts; but such acts would not constitute a full human life. Now, I have no doubt that God will grant all sorts of cognitive achievements to this disembodied soul, but considering its natural powers alone, the life of a disembodied soul would seem to be a dreamless sleep accompanied by dim self-awareness. The natural life of the disembodied human soul would appear to be a life longing for wakefulness, longing for the restoration of the flesh.

[3] What Persists Must Make the Body Be. If the resurrection is to be good news, the resurrected body must really be my body. The provincial council of Toledo formulated this requirement with admirable clarity: "And we do not believe that we shall rise in an ethereal body or in any other body, as some foolishly imagine, but in this very body in which we live and are and move." 24 According to the basic fact of death, the body has ceased to be. How then can my body that exists now, cease to exist when I die, and yet be restored as the selfsame body in the resurrection? I think it can be the same body provided that it has the same being. But it can only have the same being if that being has been held in reserve, as it were, by the persisting soul. The soul that survives must be the animating form of the flesh; it must make the body be the body it is. This means that the soul can cause to be only its own body and none other.

The resurrected body would be the selfsame body in virtue of being animated by our soul. What about our bodily remains? Mustn't they be incorporated into the resurrected body for it to 
be the selfsame body? Remember that death is destruction of the body. The promised miracle is that our bodies will be restored not that we never will have died or will have only seemed to die. And evidently death involves the demise of the body as a whole. Even a corpse artificially kept from decaying, such as Lenin's in Red Square, no longer is the body that it once was. Rather, it is a vestige that harbors no possibility of life within it; its matter has returned to subpersonal being. And many of the dead will be in the position of Father Thomas Byles, the priest who heard confessions on the sinking Titanic and whose remains have been dissolved into the sea. If the hope of resurrection for them is not to be in vain, the corpse must not be necessary for establishing the identity of the body.

Am I really saying that God could have resurrected Lazarus while leaving his corpse in the tomb? Yes, I am: Lazarus in this scenario would have his selfsame body in virtue of having his selfsame soul animating a body; the remains in the tomb are inessential. Still, it would not be fitting for God to have resurrected Lazarus while his corpse is on hand. ${ }^{25}$ He would seem like a ghost, because his corpse is a sign of his being dead. Resurrection, to present faithfully the restoration of bodily life to the one that died, should involve taking up and cancelling the sign of death. And of course, thinking of Lazarus is misleading; the hoped-for resurrection of the dead will not restore us to mortal life as with Lazarus; it will bring us to immortal life. The body raised will not be the body in the same condition as the one that died, but one in its prime and, according to Augustine, one that will be better looking than the one each of us has now. ${ }^{26}$ Thus, I grant that it may be fitting for bodily remains to somehow (I know not how) be reincorporated into the resurrected body, but it is not necessary. One will have the selfsame body thanks to one's selfsame soul that animates the body. Nor should this conclusion seem strange. Even in 
this life, after all, it is the form, rather than the ever-changing matter, that makes my body be the same through time. ${ }^{27}$ I have the same body I did ten years ago even though on the physical level I am constituted of different molecules. Even more so, soul-form, rather than material parts, establishes the identity of the body before death and after the resurrection. Any animated body would be the same body if it is animated by the same form.

What about our brains? It is worth noting, of course, that talk of "the brain" is an abstraction, for it is but part of the nervous system which is itself but part of the body as a whole; perception and experience is an activity that puts into play the entire person. ${ }^{28}$ Still, as far as bodily organs go, the brain seems to be a kind of privileged part, which therefore occasions some puzzles of its own. Can we really say that we will be the same person even though our original brains will have returned to nothingness? I think the resurrected brain will be outfitted with the same memories; it will not be a replica, however, but the same brain thanks to the identity of the immaterial animating soul. It will belong to the same one person. What, however, of our memories? These are in some sense stored neurologically whenever we undergo experiences. Certainly, these new brains have to have the same memories as the old ones. But how can they be the same memories when one was formed as the fruit of experience and another is as it were uploaded? The point, however, is not the causal origin of the memories as physically stored; the point is whether or not the numerically same person was the subject of those experiences. Consider a different situation. Say I forget where I bought a pair of shoes; on the level of my neurons, the memory of the location of that shoe-buying no longer exists. However, my wife reminds me; the fact that the memory was stored outside of me and comes to be stored in my

27. For a contemporary defense of the role of living form in organic identity, see Hans Jonas, The Phenomenon of Life (New York: Harper \& Row, 1966), pp. 64-98.

28. See Alva Nöe, Action in Perception (Cambridge, MA: The MIT Press, 2004), pp. 209-231, and Out of Our Heads: Why You Are Not Your Brain, and Other Lessons from the Biology of Consciousness (New York: Hill \& Wang, 2009). 
brain through instruction rather than experience does not compromise the reality that I myself bought the shoes at that store. However, it would compromise the reality if in fact they had been bought by someone else and my wife was misremembering or misinforming. It is the identity of the person that establishes the identity of the brain as an organ of the body and its memories as stored personal experiences. $^{29}$

\section{III.}

Kinds of Parts. Peter Geach recognizes the importance of bodily sameness without, however, adequately accounting for its possibility. He maintains that apart from the body the soul is no longer the self but "a mere remnant." Therefore, only granting the resurrection can we hope for personal immortality; the mere continued existence of this remnant would not be personal: "The existence of a disembodied soul would not be a survival of the person Peter Geach; and even in such a truncated form individual existence seems to require at least a persistent possibility of the soul's again entering into the make-up of a man who is identifiably Peter Geach. ${ }^{30}$ He affirms against dualism the contribution of the body to personal identity; he also recognizes the role of the soul's persistence in establishing continuity between the self that is alive now and the self that was alive then. The problem comes in the way he construes the soul as but "a mere remnant." It cannot mean the body makes the person again be the person it was before, for it is the soul that establishes the continuity of substance and the personal identity of the body.

29. For a non-reductive way of relating the brain and nervous system to the person as a whole, see Robert Sokolowski's fascinating discussion of "lensing" in Phenomenology of the Human Person (Cambridge, MA: Cambridge University Press, 2008), pp. 225-237.

30. "Immortality," in God and the Soul (New York: Schocken Books, 1969), p. 24. 
Now, remnant is an ambiguous term. It means "that which remains." But what makes it ambiguous is whether what remains still is or no longer is what was there before; and if it is, what kind of part it is, simply a piece or that which instantiates the whole. So, we can point to the dead rabbit and say, these are the remains of Patches. That was Patches although, as a matter of fact, it no longer is Patches. In a different scenario, we might point to a single slice of pie and identify it as the remains of the whole pie that once was. Unlike Patches' remains, the pie slice still is a slice of pie; the point is simply that the whole is no more and therefore this part is a remnant. Of course, if we bake a new pie around the remnant, we won't say it's the same pie as before. Neither of these senses of remnant fulfills the requirements for the sameness of the resurrected person. In accordance with the first criterion, we can posit the possibility of a persisting part that instantiates the whole. This is the case with the hydra, a half-inch aquatic creature, which lives for years and years by monthly regrowing its body from stem cells. Rob Steele, a hydrobiologist, described its feat as follows: "It doesn't have any cells that hang around long enough to get old and decrepit, and therefore the individual doesn't get old and decrepit." ${ }^{31}$ Similarly, the world's oldest tree is 9,950 years old despite the fact that its trunk and branches has died every 600 years or so. Leif Kullman, an ecologist who discovered this conifer, says that "as soon as a stem dies, a new one emerges from the same root stock. So the tree has a very long life expectancy. ${ }^{, 32}$ In this sense of remnant, the persisting stem cells or root stock instantiate the identity of the organism across the continual regeneration of the rest of its body.

Remnant, then, can mean (1) what's left as a result of the body's ceasing to be, which I call "residue," (2) some part of a whole that survives that demise intact, which I call "a persistent

31. Matt Simon, "Absurd Creature of the Week: This Amazing Little Critter Just Might Be Immortal," Wired, http://www.wired.com/2015/02/absurd-creature-of-the-week-hydra/.

32. James Owen, "Oldest Living Tree Found in Sweden," National Geographic, http://news.nationalgeographic.com/news/2008/04/080414-oldest-tree.html. 
part," or (3) some part that survives that demise intact and that instantiates the identity of the whole, which I call "the persistent core." ${ }^{, 33}$ What does Geach have in mind by referring to the soul as "a mere remnant"? He seems to regard both the soul and the dead body as persisting parts, albeit in different ways. He says that the disembodied soul cannot say of itself, "I am Socrates," just as the single slice of pie could not say (if it were to say) "I am the pie." Also, he thinks the corpse somehow contributes to the personal identity of the resurrected person. I think he is mistaken on both counts. First, the body is not a persisting part but a residue, and it can therefore no longer contribute to personal identity. Consider the difference between the corpse of Socrates and the body of Socrates before he died. While a disembodied soul is not a complete person, a corpse is not a person at all. The corpse is a naturally occurring likeness produced by the body's loss of being. It is closer in being to a portrait than to a person. It can no longer make a significant contribution to the personal identity of Socrates. Second, the soul is not simply a persisting part, for that is not enough to establish the sameness of the self then and now; the soul must rather be the persisting core that makes the body be; the sameness of the soul as animating principle and not the "using up" of the corpse is what makes the person the same. What is lacking in Geach's account is the specification that, while the disembodied soul is not the whole person, it is nonetheless the root and ground of the person and only therefore is the resurrected person's body the same body as before. The soul is not just a persistent part; it is the personal core.

IV.

33. The term, "persistent core," is similar to John Haldane's notion of "residual substance." See "The Examined Death and the Hope of the Future," Proceedings of the ACPA 74 (2001): 254. "Persistent core" has the advantage of highlighting the causal properties that enable this part and none other to bear the full weight of personal identity. 
Thomistic Hylomorphism and Survivalism. According to the first criterion, the principle of personal persistence, versions of materialism fail to maintain personal identity; for these accounts hope in the resurrection is vain. Versions of dualism fail regarding the second and third criteria regarding the importance of the body and the role of the soul-form in establishing the sameness of the resurrected body; for these accounts hope in the resurrection is vain. However, hylomorphism in the version set out by Thomas Aquinas seems to fulfill the criteria laid out above provided it is construed along survivalist rather than corruptionist lines. According to corruptionism, death is a substantial change and therefore the separated soul is neither a human being nor a person until it is reunited with its bodily residue. According to survivalism, the persistence of the soul is enough to account for the persistence of the human person, and the soul, rather than some bodily residue, will make the restored body be the same body. Thomas deploys both accounts throughout his career, but survivalism is the superior one. ${ }^{34}$ Corruptionism undercuts hope in the resurrection, for unlike survivalism it cannot account for the sameness of the self now and then. Also, it in effect denies the full reality of death as the complete loss of my bodily being and instead holds that my body somehow persists through the continuous substantial changes it undergoes: my body somehow remains my body through death and decomposition, etc. so that in the future some bit of my body can be rescued and returned to me

34. Scholars typically argue for one over the other, but Silas Langley convincingly shows that Aquinas ambiguously used both accounts from his first to his last writings. "Aquinas, Resurrection, and Material Continuity," Proceedings of the ACPA 75 (2002): 135-147. For a recent presentation of survivalism, see Eleanore Stump, "Resurrection, Reassembly, and Reconstitution: Aquinas on the Soul," in Die Menschliche Seele: Brauchen wir den Dualismus? ed. Bruno Niederbacher and Edmund Runggaldier, pp. 153-174 (Heusenstamm: Ontos, 2006), and of corruptionism, see Patrick Toner, "St. Thomas Aquinas on Death and the Separated Soul," Pacific Philosophical Quarterly 91 (2010): 587-599. 
at the resurrection. ${ }^{35}$ Survivalism, by contrast, faces the fact that the body is no longer the same, for it has lost its being. ${ }^{36}$

Let me retrace the outlines of Thomas's survivalism here. He says the souls of men "remain" (remanent) apart from their bodies even though, as the form of the body, it is contrary to the nature of the soul to be apart from the body. ${ }^{37}$ In arguing that we can be perfectly happy in the beatific vision without our bodies, he makes clear that the human soul, being an intellective soul, is an odd kind of part: "The relation of the [human] soul to being is not the same as that of other parts." 38 Why not? In other animals, the part-whole structure is such that the being of the part depends on the being of the whole, so that if the whole ceases to be, the parts either cease to be or change in being: "for the being of the whole is not that of any individual part: wherefore, either the part ceases altogether to be, when the whole is destroyed, just as the parts of an animal, when the animal is destroyed; or, if they remain, they have another actual being, just as a part of a line has another being from that of the whole line." In the unique case of the animal endowed with an intellect, the soul can survive the destruction of the whole in such a way that it remains the same and retains the being of the whole:

But the human soul retains the being of the composite after the destruction of the body: and this because the being of the form is the same as that of its matter, and this is the being of the composite. Now the soul subsists in its own being, as stated in the I, 75, 2. It follows, therefore, that after being separated from the body it has perfect being and that

35. Langley tries to make sense of Thomas corruptionist account as follows: "Throughout all the substantial changes that some particular matter goes through, it still keeps some dimensions, some location, and thus some division from all other matter. There is a spatio-temporal trajectory here, even if nothing whatsoever remains numerically identical throughout it." “Aquinas, Resurrection, and Material Continuity," p. 142.

36. Survivalism, better than corruptionism, fits with Christian faith and practices: "The Church affirms that a spiritual element survives and subsists after death, an element endowed with consciousness and will, so that the 'human self' subsists, though deprived for the present of the complement of its body." "Letter of the S. Congregation for the Doctrine of the Faith on Certain Questions Concerning Eschatology," May 17, 1979, no. 3. 37. Summa Contra Gentiles, trans. Charles O’Neil (Garden City, NY: Hanover House, 1957), IV, c. 79. He argues for the fittingness of the resurrection as follows: "But nothing contrary to nature can be perpetual.

Perpetually, then, the soul will not be without the body. Since, then, it persists perpetually, it must once again be united to the body; and this is to rise again. Therefore the immortality of souls seems to demand a future resurrection of the body."

38. Summa Theologiae, I-II, q. 4, a. 5, ad 2. 
consequently it can have a perfect operation; although it has not the perfect specific nature.

Thomas calls this unique kind of subsistent part that retains the being of the whole, the "principal part." Commenting on the death of Christ in the Summa Theologiae, Thomas says that even though the subject ceases to be a complete man, it does not cease to be the same subject. Why not?

Man is said to be his own intellect, not because the intellect is the entire man, but because the intellect is the principal part of man, in which man's whole disposition lies virtually [quia intellectus est principalior pars hominis, in quo virtualiter existit tota dispositio hominis]; just as the ruler of the city may be called the whole city, since its entire disposal is vested in him. ${ }^{39}$

Consequently, the being of the resurrected body can be the same as the being of the body now, because it will be animated by the same principal part. Despite this agreement with the three criteria, Thomas says some things that might appear puzzling and challenging for the view I have laid out:

"My soul is not I." ${ }^{40}$ Does this assertion undermine the criterion of personal continuity? This is in effect Geach's suggestion, and this is the view advocated by contemporary corruptionists. However, Thomas thinks the soul is not $\mathrm{I}$ in the sense that my soul is not the entirety of what I am as a human being. Nonetheless, my soul is what makes my body be and be mine; the soul is the root and ground of my bodily being. Therefore, the disembodied soul can indeed say "I am (the principal part of) Thomas Aquinas" or more simply "I am the dead Thomas Aquinas." 41 It is just not in a position to say "I am Thomas Aquinas whole and entire." It

39. Summa Theologiae, III, q. 50, a. 4, ad. 2. Translation modified. I am thankful to Catherine Nolan for calling my attention to this passage.

40. "Man naturally desires his own salvation; but the soul, since it is part of man's body, is not an entire man, and my soul is not I; hence, although the soul obtains salvation in another life, nevertheless, not I or any man." Commentary on the First Epistle to the Corinthians, trans. Fabian Larcher, O.P. and Daniel Keating (http://dhspriory.org/thomas/SS1Cor.htm), n. 924.

41. Aquinas thinks that a disembodied human soul is not a "man" but is instead a "dead man" (homo mortuus). See Summa Theologiae, III, q. 50, a. 4. 
won't be able to say that until after the resurrection. The separated soul is identical in subject to Thomas Aquinas but not identical in totality to all that Thomas once was and will again be. ${ }^{42}$ "If the resurrection of the body is denied, it is not easy, yea it is difficult, to sustain the immortality of the soul." 43 Thomas thinks that apart from the resurrection, the immortality of the soul is hard to affirm; I, on the other hand, maintain that apart from the immortality of the soul, the resurrection of the dead is hard to maintain. Thomas's point, I take it, is in fact mine: the resurrection of the body and the immortality of the soul are conceptually interdependent. The problem is that while the latter, as a natural possibility, admits of a philosophical defense, the former, as a natural impossibility, does not.

"But which old woman nowadays would not know that the soul is immortal? Faith is capable of much more than philosophy is. "44 When it comes to the soul, Christian revelation bestows more light than the greatest of philosophical speculations. Thomas thinks the immortality of the soul is difficult to maintain according to natural principles alone. But a philosophy inspired by revelation, what John Paul II calls “Christian philosophy,” might nonetheless dare to defend philosophically the natural possibility of human immortality. Doing so without reference to theology might leave it in an embarrassing situation: the naked soul, without the body, appears an awkward thing. Thomas's anthropology, seen in this light, is a kind of philosophical anthropology worked out in reference to the resurrection. In this way, it fulfills

42. For the distinction between being identical in subject and being identical in totality, see Summa Theologiae, III, q. 50, a. 5, in which Aquinas is dealing with the special case of Christ's body.

43. "If the resurrection of the body is denied, it is not easy, yea it is difficult, to sustain the immortality of the soul. For it is clear that the soul is naturally united to the body and is departed from it, contrary to its nature and per accidens. Hence the soul devoid of its body is imperfect, as long as it is without the body. But it is impossible that what is natural and per se be finite and, as it were, nothing; and that which is against nature and per accidens be infinite, if the soul endures without the body. And so, the Platonists positing immortality, posited re-incorporation, although this is heretical. Therefore, if the dead do not rise, we will be confident only in this life." Commentary on the First Epistle to the Corinthians, n. 924.

44. "Sermon 14," Academic Sermons, trans. Mark-Robin Hoogland, C.P. (Washington, DC: The Catholic University of America Press, 2010), p. 203. He had already written, "Just one old woman knows more about these things that pertain to the faith than heretofore all philosophers." "Sermon 14," Academic Sermons, p. 202. 
the exact meaning of "Christian philosophy" articulated by John Paul II. It is "a philosophical speculation conceived in dynamic union with faith" and "includes those important developments of philosophical thinking which would not have happened without the direct or indirect contribution of Christian faith." ${ }^{45}$ Intellective hylomorphism, which maintains both the immortality of the soul and the need for the body, is just such a philosophical development. ${ }^{46}$

V.

Conclusion. For the resurrection to be good news, a very particular and peculiar understanding of human nature is required. What must we be if we can die and resurrect as the selfsame person? We must be hybrid beings, neither pure animals nor pure spirits. Like animals, we can really die, but unlike animals this does not involve a complete loss of substance, for our spiritual cores persist. Unlike pure spirits, our separated souls are essentially incomplete, for our bodies are not incidental to what and how we are. Our restored bodies can be our bodies in virtue of being formed by our persisting part, our personal core, which is our intellective soul. What is death if it is neither a substantial change (as with pure animals) nor merely an accidental change (as with pure spirits)? Death, for us humans, is a radical change that cuts deeper than an accident but not as deep as the substance. I suggest we call it a "change in property," so that the loss of bodily being modifies something essentially human without compromising the identity of the person. Just as the ability to speak is essential to us humans though we need not have it to exist

45. Fides et Ratio, n. 76.

46. In 1977, Ratzinger made this claim regarding Thomistic anthropology, which in his judgment joins "Plato and Aristotle precisely at the points where their doctrines were mutually opposed": "Compared with all the conceptions of the soul available in antiquity, this notion of the soul is quite novel. It is a product of Christian faith, and of the exigencies of faith for human thought. Only the downright ignorance of history could find this contestable." Eschatology, p. 148 and p. 149, respectively. 
as the same person we are, so our bodies are essential to us humans though we need not have them to exist as the same person each of us is. But just as the loss of language is a great personal loss that cuts us off from a whole domain of properly human activities so it is with the loss of our bodies. Consider Helen Keller's account of learning to speak: "I was born again that day. I had been a little ghost in a no-world. Now I knew my name. I was a person. I could understand people and make them understand me." ${ }^{\circ 7}$ Though she remained the selfsame personal substance in learning to speak through the initiative of her teacher, she nonetheless realized something essential to being human and to living a full human life. Similarly, though we can remain the selfsame person through death, the resurrection will restore something essential to being human and to living a full human life: our animate bodies.

Resurrection is a possibility that belongs to the agency of God the creator; I want to open up the logical space in human nature for God's effect. Unless I am mistaken, human nature must have the part-whole structure I have iterated for the hope in the resurrection not to be in vain, whatever God's power might be. To hope in the resurrection entails believing both that the body is part of me and that the root and ground of my selfhood subsists in the part of me that is not bodily. It requires survivalism rather than corruptionism. Hence, on the last day, when I, God willing, rise again, I will have the same body and fully be the same person thanks to that part of me that persists through death. Can philosophy go further than presenting the above view of human nature conditionally? Can it argue for the immortality of the soul and the soul as form of the body? I believe so, but these are extremely difficult topics for another day, another venue, 
and maybe even another philosopher. ${ }^{48} \mathrm{My}$ aim here has been more modest: simply to clarify what's implicit in our hope. ${ }^{49}$

48. For a start, see Kenneth Schmitz, "Purity of Soul and Immortality," in Texture of Being: Essays in First Philosophy (Washington, DC: The Catholic University of America Press, 2007); Robert Sokolowski, "Soul and the Transcendence of the Human Person," in Christian Faith \& Human Understanding: Studies on the Eucharist, Trinity, and the Human Person (Washington, DC: The Catholic University of America Press, 2006); and Michael Sweeney, "Allan Bloom and Thomas Aquinas on Eros and Immortality," Interpretation 23 (1996): 445-456.

49. I am thankful to Catherine Nolan, Jonathan J. Sanford, Chris Malloy, Michael Bowler, Gary Michael Gurtler, S.J., Molly Flynn, Mark K. Spencer, Turner C. Nevitt, and Isela Engelland for their critical comments on earlier versions of this paper. 